\title{
ON MELTING OF FRESH-WATER ICE IN SEA-WATER
}

\author{
By F. Loewe \\ (Department of Meteorology, University of Melbourne)*
}

\begin{abstract}
Melting at the bottom of floating ice shelves may represent an important item in the mass economy of ice sheets. Some earlier studies of the behaviour of fresh-water ice in sea-water at a temperature below $0^{\circ}$ C. are quoted.

RÉsumÉ. La fusion à la base des ice shelves flottants peut être d'une grande importance dans le bilan de masse des indlandsis. L'auteur rapporte quelques expériences anciennes du comportement de la glace d'eau douce dans l'eau de mer à une température inférieure à $0^{\circ} \mathrm{C}$.

Zusammenfassung. Schmelzung an der Unterseite schwimmender Schelfeise mag von erheblicher Bedeutung im Massenhaushalt von Inlandeisen sein. Einige ältere Versuche über das Verhalten von Süsswassereis in Seewasser mit einer Temperatur von weniger als $0^{\circ} \mathrm{C}$ werden geschildert.
\end{abstract}

THE question of melting at the bottom of floating ice shelves has recently again become of great interest. It has earlier been extensively discussed in connection with disagreements concerning the mass economy of the Ross Ice Shelf. ${ }^{\mathrm{I}, ~}{ }^{2}$ Near the border of the shelf melting seemed more likely, but lack of data prevented any definite conclusions. According to recent calculations of the mass budget of the Antarctic Ice Sheet, all other ways by which ice can be lost seem unable to remove the amount that accumulates in the interior. ${ }^{3}$ It has been suggested that the balance is established by melting on the lower side of the floating ice shelves.

Sverdrup ${ }^{4}$ has shown that the heat that becomes available if the sea-water flowing under the Maudheim Is-shelf is cooled to its freezing point, would be sufficient for considerable melting at the bottom of the shelf ice. Physical chemistry confirms that fresh-water ice melts in contact with sea-water even if the oceanic temperature is below $0^{\circ} \mathrm{C}$. Apart from the yet unsolved question how far below an ice shelf a sufficiently strong water circulation can be maintained, it seems doubtful whether such melting would be able to balance the mass budget of the ice sheet. First a considerable fraction of the melted ice will be replaced by the prevailing accumulation at the surface of the ice shelf itself and does not contribute to the de-icing of the continental glacier. Secondly, only one-third of the ice from the continent is fed into ice shelves; it is difficult to see how their melting can dispose of more than a fraction of the surplus. Thirdly, the long survival of partially stranded icebergs cannot easily be reconciled with considerable melting at their bottom. (It might incidentally be pointed out that the melting of floating ice has no influence upon the level of the sea and would not contribute to the rise of sea-level during the last decades.)

Some experimental studies have been made concerning the melting of fresh-water ice in seawater below $0^{\circ} \mathrm{C}$. The earliest ones in polar regions that have come to my knowledge are those of Hammer ${ }^{5}$ and Steenstrup ${ }^{6}$ in Greenland. Ice blocks of Io to $15 \mathrm{~kg}$. weight which had been suspended at depths from the surface to $10 \mathrm{~m}$. in sea-water of 3.4 per cent salinity and with a temperature in March of $-\mathrm{I} \cdot 6^{\circ}$ to $-\mathrm{I} \cdot 3^{\circ} \mathrm{C}$., in April of $-1 \cdot 3^{\circ}$ to $-\mathrm{I} \cdot 2^{\circ} \mathrm{C}$. showed after a few hours marked ablation and disappeared in two to three days.

Further studies were made by members of the Ross Sea party of the Imperial TransAntarctic Expedition I9I4-1 7. A member of the party, Mr. A. K. Jack of Melbourne, has kindly made these observations available. At Cape Evans cubes of glacier ice of side lengths of 15 to $20 \mathrm{~cm}$. were immersed to different depths from near the surface to $45 \mathrm{~m}$. below the sea ice. In a few cases the temperature of the water was measured. Blocks that were left in the water from 9 to 26 August I 9 I 5 , at the height of Winter, showed a distinct increase in weight. Cubes that had been immersed on 3 October I9I 6 gained weight until i 8 October. On 16 November the blocks had slightly decreased but were still heavier than at the time of their immersion. The growth was stronger at greater depths. On 5 December the ice had completely

* Present address: Institute of Polar Studies, Ohio State University, Columbus, Ohio. 
melted. Sea-water temperatures in August showed from the surface to the bottom uniform temperatures which were practically those of the freezing point of the water; as the corrections are unknown no quite definite values can be given.

From I I to I4 and from I 6 to I9 December seven blocks of about $2.5 \mathrm{~kg}$. each between the surface and $47 \mathrm{~m}$. had all disappeared from their lashings. On 20 December a new series of seven blocks was immersed. At this time the surface temperature of the water was $-\mathrm{I} \cdot 7^{\circ} \mathrm{C}$., about $0.15^{\circ}$ above freezing point. To prevent them from slipping out of their lashings, the blocks at the surface and at a depth of $9 \mathrm{~m}$. were enclosed in netting. Already after 4.5 hours the blocks showed an appreciable decrease. After 24 hours those in lashings had disappeared. Of those kept in nets the surface block was after 53 hours reduced from $9 \mathrm{~kg}$. to $2 \mathrm{~kg}$., and the block at $9 \mathrm{~m}$. from $6 \mathrm{~kg}$. to a very small remnant. After ioo hours the block near the surface had dissolved. Cubes of weights of about $5 \mathrm{~kg}$., among them one at the bottom at $47 \mathrm{~m}$. depth, immersed on 25 December had disappeared after about 24 hours.

Evidently at the bottom of an extended level ice sheet, particularly far from the border with a very sluggish water circulation, the rate of melting will be much smaller than that of small blocks of ice with relatively big surfaces exposed to a lively motion of the water. But the observations suggest that with water temperatures below $0^{\circ} \mathrm{C}$. appreciable melting can occur even if the water temperature is less than one degree above its freezing point.

In view of the possible importance of melting at the bottom of ice shelves new experimental and theoretical studies of the problem as in the recent work of Crary ${ }^{7}$ seem justified.

MS. received 9 May $19^{61}$

\section{REFERENCES}

I. Wright, C. S. The Ross Barrier and the mechanism of ice movement. Geographical Fournal, Vol. 65, No. 3, I925, p. $198-220$.

2. Debenham, F. The problem of the Great Ross Barrier. Geographical fournal, Vol. I I2, Nos. 4-6, I948, p. I96-2 I8.

3. Wexler, H. Ice budgets for Antarctica and changes in sea-level. Fournal of Glaciology, Vol. 3, No. 29, r96 r, p. $867-72$.

4. Sverdrup, H. U. The currents off the coast of Queen Maud Land. Norsk Geografisk Tidsskrift, Bd. I4, Nr. I-4, 1953, p. 239-49.

5. Hammer, R. R. I. Undersøgelser ved Jakobshavns isfjord og naermeste omegn i vinteren $1879-80$. Meddelelser om Gronland, Bd. 4, I883, p. I-67.

6. Steenstrup, K. J. V. Bidrag til kjendskab til braeerne og brae-isen i nord-Grønland. Meddelelser om Gronland,

Bd. 4, I883, p. $69^{-112 .}$. Crary, A. P. Glaciological regime at Little America station, Antarctica. Fournal of Geophysical Research,
7. Vol. 66,1961, p. $871-78$. 